\title{
Indonesian Labor Sector During Covid-19 : Weighing the Impact of Company Saving Policy and Workers Protection
}

\author{
Kadek Agus Sudiarawan', Putu Devi Yustisia Utami' ${ }^{2}$, \\ Gede Agus Angga Saputra ${ }^{3}$, Alia Yofira Karunian"
}

\author{
${ }^{1}$ Faculty of Law, Udayana University, E-mail:agus_sudiarawan@unud.ac.id \\ 2Faculty of Law, Udayana University, E-mail: deviyustisia@unud.ac.id \\ 3RAH Legal Experts Law Office, E-mail: gedeagus209@gmail.com \\ 4The Institute for Policy Research and Advocacy, E-mail : alia@elsam.or.id
}

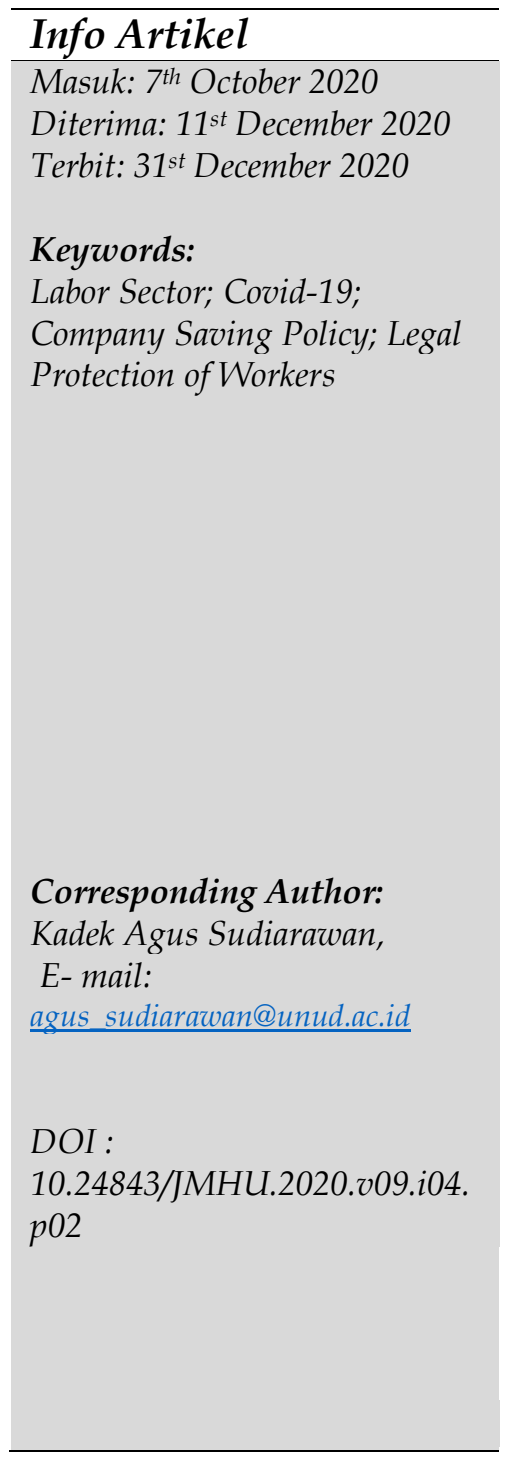

\begin{abstract}
The COVID-19 pandemic has a very significant impact on the global economy, especially in the business sector, which has suffered significant losses. On this matter it is deemed necessary to carry out research with the objectives first, to determine whether the policies implemented by companies in the form of employment termination and temporary workers layoff in order to survive the company can be legally justified, second, to determine what forms of legal protection should be obtained by workers in an industrial relationship with companies amidst of COVID19, and third, to determine what forms of work relations/alternative policy models that can be offered to companies to be able to ease the burden on the company while being able to provide protection for workers amidst COVID-19. Research method that is applied is normative legal research with a statutory approach and legal concepts. The results show that company policies in the form of layoffs during the COVID-19 pandemic can be justified as long as they comply with the provisions of Article 163 to Article 165 of the Manpower Law, the act of laying off workers can be justified as long as it complies the provisions of the Minister of Manpower Circular Letter Number 5/1998 and Minister of Manpower Circular Letter Number 907/2004. Legal protection that shall be obtained if a worker is laid off must comply with the provisions of Article 156 of the Manpower Law. Companies can implement an industrial relationship by implementing Work From Home (WFH) during the COVID-19 pandemic.
\end{abstract}




\section{Introduction}

Currently the world community is being shocked by the emergence and spread of the Corona Virus Diseases (COVID-19) disease outbreak which first appeared in China at the end of 2019. Until now the spread of COVID-19 has been very fast so that it has caused more victims in various countries in Indonesia. world. Due to the rapid spread of the COVID-19 virus the World Health Organization (WHO) on March 11, 2020 announced that the COVID-19 Virus was designated as a Global Pandemic outbreak.

Indonesia is included in the list of countries where the COVID-19 spreads. The COVID19 pandemic not only has an impact on health but the economic sector has also been hit by the spread of COVID-19. In the first quarter of 2020, Indonesia's economic growth rate fell from just over 5\% to under 3\%, compared with the first quarter in $2019 .{ }^{1}$ As a result, the Government issued various appeals, such as to carry out social distancing, physical distancing, self-quarantine and appeals to work from home. These containment and mitigation measures require a reduction in economic activity ${ }^{2}$, affecting businesses that rely on social gathering and physical presence (e.g. tourism) and labour-intensive manufacturing plants. ${ }^{3}$ All of these affect production and sales in the business sector. The business sector that has encountered the most impact from the spread of the COVID-19 pandemic is in the trade, tourism, hotel accommodation and restaurant sectors, and it is undeniable that other business sectors are also affected by the COVID-19 pandemic.

The COVID-19 pandemic has put workers even in more uncertain situations. Preliminary analysis by the International Labour Organization (ILO) estimates a significant rise in global unemployment between 5.3 million and 24.7 million. ${ }^{4}$ Based on data from the Ministry of Manpower as of 1 May 2020, the number of formal sector workers who have been dismissed due to the COVID-19 pandemic has reached $1,032,960$ people. Meanwhile, the number of laid-off formal and informal sector workers has reached 689,998 people. Thus, the total number of formal and informal sector workers affected by COVID-19 is 1,722,958 people $^{5}$.

This situation is the biggest test for workers to negotiate their fate with employers and the government. Existing policy instruments must be examined carefully and thoroughly to see opportunities for strength as the basis of arguments for workers in negotiations with employers and the government. Manpower policies have regulated

${ }^{1}$ Olivia, S., Gibson, J., \& Nasrudin, R. A. (2020). Indonesia in the Time of Covid-19. Bulletin of Indonesian Economic Studies, 56(2), 143-174. DOI: 10.1080/00074918.2020.1798581, accessed on 4th October 2020.

2 Martin S. Eichenbaum, et.al., (2020) "The Macroeconomics of Epidemics", NBER Working Paper 26882, National Bureau of Economic Research, https://www.nber.org/papers/w26882, (accessed on 4th October 2020).

3 Susan Olivia, et.al., op.cit, h. 146.

${ }^{4}$ International Labour Organization, (2020) "COVID-19 and the world of work: Impact and policy responses":3. Available from https://www.ilo.org/wcmsp5/groups/public/--dgreports/---dcomm/documents/briefingnote/wcms_738753.pdf. (accessed on 4th October 2020).

${ }^{5}$ See on "Kena PHK di Tengah Corona, Bisakah Tuntut Perusahaan?" https:// finance. detik. Com /berita-ekonomi-bisnis/d-5010998/kena-phk-di-tengah-corona-bisakah-tuntut-perusahaan. (accessed on $16^{\text {th }}$ of May 2020). 
the relationship between workers and employers in such a way, and in the event of a dispute or dispute over industrial relations each has a basis for fighting for their rights.

Law Number 13 Year 2003 concerning Manpower (hereinafter referred to as the Manpower Act) is an umbrella act for workers. Policies that specifically contain guidelines and dispute resolution mechanisms are regulated in Law Number 2 Year 2004 concerning the Industrial Relations Disputes Settlement (hereinafter referred to as the "PPHI Law"). For each industry, this Law will then be implemented into Company Regulations (CR), and Collective Labor Agreements (CLA), as well as Work Agreement (PK) which were made based on bargaining agreements between workers, trade unions or labor unions and employers.

The PPHI Law also regulates the dispute resolution mechanism for each type of dispute, which is generally known as the Bipartite mechanism, namely direct negotiations between workers, trade unions or labor unions and employers, then a tripartite mechanism facilitated by the Manpower Office with options through Mediation, Conciliation and/or Arbitration. If the tripartite mechanism fails, then it is possible to take the further step of the Industrial Relations Court. ${ }^{6}$

On this situation, Government through the Coordinating Minister for Political, Legal and Security Affairs, Prof. Dr. Mahfud Md, when giving an explanation regarding the issuance of Presidential Decree Number 12 Year 2020 concerning the determination of the Coronavirus (COVID-19) outbreak (hereinafter referred to as "Presidential Decree $12 / 2020^{\prime \prime}$ ) as a non-natural national disaster, it was stated that employers were not allowed to impose force (force majeure) on the basis of this Presidential Decree. The Presidential Decree was actually stated as an opportunity for workers/labors to renegotiate with employers. ${ }^{7}$

A similar statement was also conveyed by the Minister of Manpower and Transmigration, Ida Fauziah, when giving an explanation of the purpose of issuing a Circular of the Minister of Manpower Number M/3/HK.04/III/2020 concerning Protection of Workers/Labors and Business Continuity in the Context of Prevention and Disaster Management of COVID -19 (hereinafter referred to as "Minister of Manpower Circular Letter 3/2020") signed on 17th of March 2020 addressed to all Governors throughout Indonesia. On this occasion it was explicitly stated that between employers and workers must promote social dialogue in dealing with the impact of COVID 19.8

In the current state of the COVID-19 Pandemic, there is a gap that can be interpreted in various ways, namely whether the current conditions can be used as a strong reason for employers to lay off workers in their companies. From the description above, it seems that there are still problems between workers and employers. Therefore, it is

\footnotetext{
${ }^{6}$ Sudiarawan, K. A., \& Dananjaya, N. S. (2018). KONSEP PENYELESAIAN PERSELISIHAN HUBUNGAN INDUSTRIAL BERBASIS PEMBERDAYAAN SEBAGAI UPAYA PENINGKATAN PERLINDUNGAN HUKUM TERHADAP BURUH DALAM MENCARI KEADILAN. ADHAPER: Jurnal Hukum Acara Perdata, 3(1), 1737.http://jhaper.org/index.php/JHAPER/article/view/42, (accessed on 18 th of May 2020).

7 Joseph Ginting, (2020), 2,8 Juta Buruhdi-PHK Dan Dirumahkan Di Tengah COVID-19, https://www.riauonline.co.id/citizen / /read/2020/05/01/28-juta-buruhdi-phk-dandirumahkan-di-tengah-COVID-19. (Accessed on 18th of May 2020).

8 Ibid.
} 
interesting to discuss further on "Indonesian Labor Sector During COVID-19: Weighing the Impact of Company Saving Policy and Workers Protection".

The author conducted a review of several previous studies, where there were several similar articles discussing legal protection of labor but with a different focus of study from this paper. Prajnaparamitha in his research entitled "Protection of Work Status and Wages of Workers in the Situation of the COVID-19 Pandemic Based on the Perspective of Legal Reform" put more focuses on the status of the workforce and the wage system received by workers during the COVID-19 pandemic. ${ }^{9}$ In another article, M. Mustakim in his research entitled "The COVID-19 Pandemic As a Reason for Force Majeure in Conducting Employment Termination in Indonesia" put more focuses on discussing the analysis of the COVID-19 conditions which qualify as force majeure as a reason for terminating employment for employee. ${ }^{10}$ These two writings have a different focus from this paper, where this paper focuses on analyzing company policies not only in laying off workers but also on the actions of employers in laying off workers in the midst of the COVID-19 pandemic from a positive legal perspective in Indonesia, apart from that this research also focuses on legal relations and forms of work relations/alternative policy models that can be taken by companies during the COVID-19 pandemic that does not harm companies or workers. It can be said that the writings in previous publications have problem formulations, objectives and discussion focuses that are different from this paper. Based on the explanation above it is interesting to study about : 1 . Whether the policies implemented by the company in the form of employment termination and temporary workers layoffs in order to survive the company are legally valid? 2. What form of legal protection should be received by workers in a working relationship with companies amid COVID-19? and 3. What forms of work relations/alternative policy models can be offered to companies to ease the burden on the company while providing protection for workers amid COVID$19 ?$

\section{Research Method}

This paper uses a type of normative legal research. Normative legal research is legal research whose object is to examine norms. This paper uses a statute approach and a conceptual approach. Sources of legal materials that the authors use are primary legal materials derived from national legal documents, international legal documents and scientific journals about labor law. Secondary legal materials which become supporting materials such as books used which are compiled with literature study techniques and analyzed and presented with descriptive techniques. The legal materials were then collected using systematization techniques, followed by analysis based on descriptive techniques, interpretation and argumentation.

\footnotetext{
${ }^{9}$ Prajnaparamitha, K., \& Ghoni, M. R. (2020). Perlindungan Status Kerja Dan Pengupahan Tenaga Kerja Dalam Situasi Pandemi COVID-19 Berdasarkan Perspektif Pembaharuan Hukum. Administrative Law \& Governance Journal, 3(2), 314-328.

${ }^{10}$ Mustakim, M., \& Syafrida, S. (2020). Pandemi Covid-19 Sebagai Alasan Force Majeure Dalam Melakukan Pemutusan Hubungan Kerja di Indonesia. SALAM: Jurnal Sosial dan Budaya Syar-i, 7(8), 695-706.
} 


\section{Result and Discussion}

\subsection{Policies Implemented by the Company in the Form of Employment Termination and Temporary Workers Layoff in Order to Survive the Company.}

In the dynamics of employment in Indonesia, work relations do not necessarily run smoothly, it is very possible for disputes to arise which can be caused by the worker or the company. Among them are workers who feel aggrieved by company policies, as well as companies that feel aggrieved by workers' negligence. The current COVID-19 pandemic is very likely to have an impact on layoffs in companies. Several companies were found to have issued policies to terminate working relations with some workers which were felt to increase the company's losses. ${ }^{11}$ In fact, there are 5 (five) legal products that a company must pay attention to before taking layoffs against workers, namely: Manpower Law; Company Regulations (CR); Collective Labor Agreement (CLA); Work Agreement (WA) and; PPHI Law. ${ }^{12}$

Basically, the regulation regarding layoffs is stipulated in Chapter XII Article 150 to Article 172 of the Manpower Law. In Article 1 point 25, it is stated that: "Termination of employment is the termination of a work relationship due to certain matters resulting in the termination of rights and obligations between workers/labors and entrepreneurs".

The several types of Termination regulated in the Manpower Law include:13

\section{a. Termination by Law}

Termination of employment (PHK) by law can only occur due to the reason that the agreed working time limit has expired or if the worker dies.

\section{b. Termination by Workers/Labors}

Termination by the worker / labor is a termination made before the end of the work agreement which is the right and authority of the worker either with the consent or done unilaterally by the worker.

\section{c. Termination by Employers/Employers}

As stipulated in Article 163 to Article 165 of the Manpower Law, the reasons for an entrepreneur to terminate a worker / labor are as follows:

a) mass termination because the company has closed down due to continuous losses accompanied by financial evidence that has been

11 Joseph Ginting, (2020), 2,8 Juta Buruhdi-PHK Dan Dirumahkan Di Tengah COVID-19, https:// www.google.com /search?q =journal+hukum+perlindungan+hukum+pekerja+terkena+dampak+PHK\&rlz=1C1CHBD_id ID909ID909\&oq=journal+hukum+perlindungan+hukum+pekerja+terkena+dampak+PHK\&a $\mathrm{qs}=$ chrome. $69 \mathrm{i} 57.18542 \mathrm{j} 0 \mathrm{j} 7 \&$ sourceid $=$ chrome\&ie=UTF-8\#, (Accessed on 21 ${ }^{\text {st }}$ of July 2020).

12 Pangaribuan, Juanda, (2018),Tata Cara Melakukan Pemutusan Hubungan Kerja Berdasarkan Undang-Undang No. 13 Tahun 2003", tersedia pada https://www. hukumonline.com/ berita / baca / lt5af2b67c1ec5d / formula-tepat-melakukan-phk-secara-hukum/, (Accessed on 28 $8^{\text {th }}$ of April 2020).

${ }^{13}$ See Article 1 number 25 Law of Republic of Indonesia Number 13 Year 2003 concerning Manpower. 
audited by a public accountant for at least 2 (two) years, or a force majeure;

b) mass termination because the company closed because the company was doing efficiency;

c) Termination of employment due to a change in status or change in ownership of the company in part or in whole or the company has moved location with the same new terms of work as the old terms of employment and the worker is not willing to have a working relationship;

d) Termination due to a change in status or change in ownership in part or in full or the company has moved locations with the employer not willing to accept workers in his company for any reason. ${ }^{14}$

Another reason for employers to be able to terminate the employment relationship is due to an error from the worker himself, whether it is a minor error or a serious mistake committed by the worker in carrying out his obligations as an employee.

\section{d. Termination Due to Court Decisions}

Termination of employment due to a court decision, either an industrial relations court or including a decision issued by a district court for a criminal case. Employers can terminate their employment through a district court on the grounds that the worker has committed a serious mistake as regulated in Article 158 paragraph 1 of the Manpower Law.

In essence, in employment termination, the important thing is regarding the validity of the status of workers in the employment relationship and the validity of the reasons for the termination of employment. As has been described above, that new employers can terminate the employment relationship in which case the worker makes minor or serious mistakes as regulated in Article 163 to Article 165 of the Manpower Law. The reasons that are not permitted for employers to terminate employment are related to the unilateral termination of employment outside as stipulated in Article 163 to Article 165 of the Manpower Law. Associated with the COVID-19 pandemic, the current pandemic condition can be qualified as a force majeure condition. The principle of force majeure which was originated from Roman Law ${ }^{15}$ is a principle that allows a party to terminate its obligations under a contract because of the occurrence of an extraordinary event that is unforeseen, beyond the parties' control, and preventing the party from its

\footnotetext{
${ }^{14} \mathrm{Hadi}, \mathrm{A}$. (2019). PERLINDUNGAN HUKUM TERHADAP KARYAWAN YANG MENGALAMI PEMUTUSAN HUBUNGAN KERJA SETELAH PUTUSAN PENGADILAN BERKEKUATAN HUKUM TETAP. Jurnal Surya Kencana Satu: Dinamika Masalah Hukum dan Keadilan, 9(2), $53-$

70.https://www.researchgate.net/publication/335272188_PERLINDUNGAN_HUKUM_TE RHADAP_KARYAWAN_YANG_MENGALAMI_PEMUTUSAN_HUBUNGAN_KERJA_SET ELAH_PUTUSAN_PENGADILAN_BERKEKUATAN_HUKUM_TETAP , (Accessed on 18th of May 2020).

${ }^{15}$ Marel, Katsivela, (2020), "Contracts: Force Majeure Concept of Force Majeure Clauses?", Uniform Law Review - Revue de Droit Uniforme, 12(1), pp.101-102, DOI: 10.1093/ulr/12.1.101, Accessed on 4th October 2020.
} 
obligation. ${ }^{16}$ The principle of force majeure includes both acts of nature (natural disaster) and acts of people (riots, strikes and wars). ${ }^{17}$ In the case at hand, COVID-19 pandemic can be qualified as that of a natural disaster. ${ }^{18}$

The principle of force majeure is enshrined in several international legal instruments such as Article 7.1.7(1) of the UNIDROIT Principles of International Commercial Contracts ${ }^{19}$, furthermore, Act No. 3 Presumed Force Majeure Event by the International Chamber of Commerce (ICC) Forcemajeure and Hardship Clauses (March 2020) explicitly includes "plague, epidemic, natural disaster or extreme natural event" as events that can be qualified as force majeure. ${ }^{20}$ Thus, when in this situation, when an entrepreneur feels that they are no longer able to employ his workforce, layoffs can be done but only as a last resort. ${ }^{21}$

Termination should only be done as a last resort as an effort to improve company efficiency after previously other efforts were made in the context of efficiency. The company cannot conduct termination of workers before taking the several steps that have been determined in the Circular of the Minister of Manpower and Transmigration of the Republic of Indonesia Number: 907/MEN/PHI-PPHI/X/2004 concerning Prevention of Mass Termination of Employment Relationships (hereinafter referred to as "Minister of Manpower Circular Letter 907/2004" ).22

Furthermore, regarding the policy implemented by the company in the form of employment termination and temporary workers layoff in order to survive the

${ }^{16}$ Larry A. Dimatteo and Lucien J. Dhooge, (2004), International Business Law, a Transactional Approach, Thomson West ed., 2nd ed, pp.134-135, accessed on 4th October 2020; See also Carter B. Casady and David Baxter, "Pandemics, public-private partnerships (PPPs), and force majeure | COVID-19 expectations and implications", Construction Management and Economics, 2020, p.2, DOI: 10.1080/01446193.2020.1817516, accessed on 4th October 2020.

17 Bryan Garner and Henry Campbell, (2019), Black's Law Dictionary, 11th ed., Thomson Reuters, p.788.

${ }^{18}$ Klaus Peter Berger and Daniel Behn, (2020), "Force Majeure and Hardship in the Age of Corona: A Historical and Comparative Study", McGill Journal of Dispute Resolution, 6(4), p.81, DOI: http://dx.doi.org/10.2139/ssrn.3575869, accessed on 4th October 2020.

19 Article 7.1.7(1) regulates that "Non-performance by a party is excused if that party proves that the non-performance was due to an impediment beyond its control and that it could not reasonably be expected to have taken the impediment into account at the time of the conclusion of the contract or to have avoided or overcome it or its consequences"; See UNIDROIT Principles of International Commercial Contracts, pp.240-242, https://www.unidroit.org/english/principles/contracts/principles2016/principles2016e.pdf, accessed on 4th October 2020.

20 International Chamber of Commerce Force Majeure Clause, 2020, point.3(e), p.2, https://iccwbo.org/content/uploads/sites/3/2020/03/icc-forcemajeure-hardship-clausesmarch2020.pdf, accessed on 4th October 2020.

${ }^{21}$ Romlah, S. (2020). Covid-19 Dan Dampaknya Terhadap Buruh di Indonesia. 'ADALAH, 4(1), h. 219

22 Putri, Ayu Ratna Hari (2016), Perlindungan Hukum Terhadap Hak-Hak Pekerja Yang Terkena Pemutusan Hubungan Kerja Akibat Efisiensi Perusahaan Berdasarkan Undang-Undang Nomor 13 Tahun 2003 tentang Ketenagakerjaan Di Kota Semarang(Studi Putusan Ma Nomor 474/K/Pdt.SusPhi/2013), Jurnal Hukum Ketenagakerjaan, Vol. 5, No. 2, Tahun 2016, https://ejournal3.undip.ac.id/index.php/dlr/article/view/11102, accessed on 28th April 2020. 
company, that previously the term "to house or be sent home" was not stipulated in the Manpower Law. Regarding the term "sent home" can refer to the provisions of Minister of Manpower Circular Letter 907/2004 letter f which categorizes "dismiss or lay off workers/labors on a temporary basis" as an effort that can be done before termination of employment. Then, this term can also be found in the Minister of Manpower Circular Letter No. SE-05/M/BW/1998 of 1998 concerning Wages of Workers who are Sent Home Not in the Direction of Termination of Employment (hereinafter referred to as "Minister of Manpower Circular Letter 5/1998").

Termination of workers is the same as leaving/freeing workers from doing work until the time determined by the company. This is done by the company as a first step to reduce company expenses or because there is no activity/production carried out by the company so that it does not require labor for a while. Therefore, because the Manpower Law does not regulate the act of "laying home", then referring to the Minister of Manpower Circular Letter 907/2004 and Minister of Manpower Circular Letter 5/1998, the act of laying off workers which is a company policy as a form of surviving the company is one effort that can be justified, provided that, the policy to house workers taken by employers must meet the requirements as specified in Minister of Manpower Circular Letter 5/1998 and Minister of Manpower Circular Letter $907 / 2004$.

In addition, this research was carried out concurrently with legislation process of Law Number 11 of 2020 concerning Job Creation (hereinafter referred to as the Job Creation Law) which caused various pros and cons in the society, specifically from the employment side in responding to the various regulatory changes related to Industrial Relation in the manpower cluster of the related law.

The Job Creation law specifically in manpower cluster is generally directed at strengthening the protection of the employment and increasing the role and the welfare of the employment in supporting the investment ecosystem. This regulation amend, removes, or sets new regulations for several provisions regulated, one of which is the Employment Law related to Termination of Employment. It is also regulated that in addition to the reasons for Termination of Employment as referred to in paragraph (1), other reasons for Termination of Employment can be stipulated in the employment contract as referred to in Article 61 paragraph (1) and further provisions regarding procedures for Termination of Employment are regulated in a Government Regulation.

\subsection{Form of Legal Protection That Should be Obtained by Workers in a Working Relationship with Companies During the Pandemic of COVID-19}

Manpower Law regulates the working relationship between workers/labors and entrepreneurs, which means regulating the interests of private individuals. The work relationship that regulates workers and employers basically contains the rights and obligations of the parties. The meaning of rights and obligations is always reciprocal between one another. The rights of workers or labors are the obligations of employers and vice versa. The employment relationship cannot be separated from the work 
agreement made by the parties. The agreement that is made can be in the form of an agreement that contains information on certain matters and is signed by the parties. ${ }^{23}$

Every legal relationship that is born because of an agreement or statutory regulation always has two aspects, namely rights and obligations. Rights are interests that are protected by law. The right to provide enjoyment and flexibility to individuals in the implementation. Obligations is a positive legal norm that instructs individual behavior by imposing sanctions for the opposite behavior. This right arises when an obligation has been carried out. Rights and obligations are two things that are closely related, because there will be no rights if the obligations are not carried out properly. ${ }^{24}$ The rights and obligations stipulated in the agreement must be carried out as well as possible, so that neither party commits a violation. ${ }^{25}$ In the Manpower Law, this work relationship is regulated, in which the working relationship that is formed between a Worker/Labor and an Employer/Company must be in the form of: Company Regulations; Collective Labor Agreement, Work Agreement; Work Agreement with Specified Period of Time (PKWT); Work Agreement with Unspecified Period of Time (PKWTT).

Juridically, as regulated in Article 5 of the Manpower Law, it is stated that "every worker has the same opportunity without discrimination to get a job". In the elucidation of Article 5 of the Manpower Law explains:

"Every worker has the same rights and opportunities to obtain a decent job and livelihood regardless of gender, ethnicity, race, religion and political orientation according to the interests and abilities of the workforce concerned, including equal treatment of person with disabilities"

Furthermore, Article 6 of the Manpower Law states that "every worker/labor has the right to receive equal treatment without discrimination from the entrepreneur". In the elucidation of Article 6 of the Manpower Law, it explains that "Entrepreneurs shall give rights and obligations to workers/labors regardless of gender, ethnicity, race, religion, skin color, and political orientation".

The term protection means to protect, fortify, defend and prevent. ${ }^{26}$ The scope of protection for workers/labors according to the Manpower Law covers: 1. Protection regarding wages, welfare, social security for workers; 2. Protection of occupational safety and health; 3 . Legal protection for establishing and becoming members of labor unions; 4 . Protection of workers/labors' basic rights to deliberating with entrepreneurs;

Legal protection that should be obtained by workers in a working relationship with a company in the midst of COVID-19, namely if the worker is laid off, the worker has the right to receive severance pay of 1 (one) time as stipulated in Article 156 paragraph (2) of the Manpower Law, work reward money. in the amount of 1 (one) time as stipulated in Article 156 paragraph (3) of the Manpower Law, and compensation for rights according to Article 156 paragraph (4) of the Manpower Law.

${ }^{23}$ Utami, P. D. Y., Diantha, I. M. P., \& Sarjana, I. M. (2018). Kedudukan Hukum Grosse Akta Pengakuan Hutang Notariil dalam Pemberian Kredit Perbankan. Acta Comitas: Jurnal Hukum Kenotariatan, 3(1), 201-214.

${ }^{24}$ Mertokusumo,Sudikno, (2000), Mengenal Hukum :Suatu Pengantar, Liberty, Yogyakarta, p. 41.

${ }^{25}$ Ibid.

${ }^{26}$ Kusumawati, M. P. (2020). Perlindungan Hukum Pekerja Pasca Phk Melalui Pengunduran Diri. Literasi Hukum, 4(1), 52-61, p. 57. 
Legal protection that should be obtained by workers in a working relationship with a company in the midst of COVID-19, namely if the worker is sent home, then refer to the Minister of Manpower Circular Letter 5/1998 regulates:

- Employers continue to pay wages in full, namely in the form of basic wages and fixed benefits as long as the workers are dismissed, unless otherwise stipulated in the Work Agreement, Company Regulations or Collective Labor Agreement.

- If the employer will not pay the workers' wages in full, the employer shall negotiate with the union and/or workers about the amount of wages during the time they are sent home. ${ }^{27}$

Then based on the Minister of Manpower Circular Letter 907/2004 which regulates the following matters:

If a company experiences difficult situation that can affect employment, the company shall applies the following:

- Reducing wages and facilities for upper-level workers;

- Reducing Shift;

- Reducing Working Hours;

- Reducing the Working Day;

- Leave or lay off workers/labors on a temporary basis. ${ }^{28}$

Thus, if a worker/labor is sent home due to a public health emergency such as COVID19, the worker/labor who is sent home is still entitled to receive full wages or wage deductions if it has been agreed by the company and the worker.

The deduction of employee wages has basically been regulated in Government Regulation Number 78 Year 2015 concerning Wages (hereinafter referred to as "Government Regulation of Wages") with certain conditions. Wage components based on Article 5 paragraph (1) Government Regulation of Wages consist of:

1. Wages without allowances;

2. Basic wage and fixed allowances; or

3. Basic wage, fixed allowance, and non-permanent allowance. ${ }^{29}$

The deduction of wages by employers is carried out in accordance with the work agreement, company regulations, or collective labor regulations for:

1. a fine;

2. compensation; and/or

3. advance wages

\footnotetext{
27 See Minister of Manpower Circular Letter No. SE-05/M/BW/1998 of 1998 concerning Wages of Workers who are Sent Home Not in the Direction of Termination of Employment.

${ }^{28}$ See Circular of the Minister of Manpower and Transmigration of the Republic of Indonesia Number: 907/MEN/PHI-PPHI/X/2004 concerning Prevention of Mass Termination of Employment Relationships.

${ }^{29}$ See Article 5 paragraph (1) Government Regulation Number 78 Year 2015 concerning Wages.
} 
On the other hand, there are wages deductions by employers that must be made based on a written agreement or a written agreement, namely for:

1. payment of debts or debt repayments of workers/labors; and/or

2. rent a house and/or rent property owned by the company which is leased by the entrepreneur to workers/labors.

However, it needs to be underlined, the total amount of wage deductions is at most $50 \%$ of each wage payment received by workers / labors. Thus, from the explanation above, the reason for cutting workers' wages due to companies losing money as a result of COVID-19 is not based on law and can lead to industrial relations disputes, namely disputes over rights.

Thus, so that the company does not violate the law and the legal protection of workers is protected, it is more appropriate for the company to postpone the payment of wages (if the employer is unable to pay wages according to the minimum wage) as allowed in Article 90 paragraph (2) of the Manpower Law which confirms that for employers those who are unable to pay the minimum wage may be deferred. Regarding the procedure for postponing the minimum wage is regulated in the Decree of the Minister of Manpower and Transmigration Number KEP-231/MEN/2003 Year 2003 concerning Procedures for Postponement of Implementation of Minimum Wages (hereinafter referred to as "Minister of Manpower Decree 231/2003").

Thus, if the company experiences loss due to COVID-19 and has not been able to pay its workers' wages according to the minimum wage, then the company can postpone wage payments by first conducting negotiations with workers/labor or /labor unions regarding the postponement. However, the postponement of the payment of minimum wages by employers to workers/labors does not automatically eliminate the obligation of employers to pay the difference in minimum wages during the postponement period.

In the face of COVID-19, the opportunity for employers to lay off workers, cut or not pay workers' wages, change the method of paying wages, can refer to the Circular of the Minister of Manpower Number M/3/HK.04/III/2020 of 2020 concerning Protection of Workers/Labors and Sustainability Efforts in the Context of Prevention and Overcoming COVID-19 (hereinafter referred to as "Minister of Manpower Circular Letter 3/2020"). Minister of Manpower Circular Letter 3/2020 was established in connection with the increasing spread of COVID-19 in several regions of Indonesia and paid attention to the official WHO statement declaring COVID-19 a global pandemic.

Point II of Minister of Manpower Circular Letter 3/2020 regulates:

a. For workers/labors who are categorized as People Under Monitoring (ODP) COVID-19 based on a doctor's statement so that they cannot come to work for a maximum of 14 days or according to Ministry of Health standards, their wages are paid in full.

b. For workers/labors who are categorized as suspected cases of COVID-19 and are quarantined/isolated according to a doctor's statement, their wages are paid in full during the quarantine/isolation period. 
c. For workers/labors who do not come to work because they are infected COVID-19 and it is proven by a doctor's statement, the wages are paid according to the laws and regulations.

d. For companies that limit their business activities due to government policies in their respective regions for the prevention and control of COVID-19.30

By considering the continuity of the business, changes in the amount and method of payment of workers' wages shall be made in accordance with the agreement between the employer and the worker.

\subsection{Forms of Work Relationships/Alternative Models of Policies That Can be Offered to Companies to Ease the Burden of the Company and be Able to Provide Protection for Workers During Pandemic of COVID 19.}

An employment relationship is a relationship that arises as a result of a work agreement made or mutually agreed upon by the entrepreneur and the worker/labor. ${ }^{31}$ An alternative form of work relationship/policy alternative model that can be offered to companies to ease the burden on the company while providing protection for workers amid COVID-19 is that companies can implement Work From Home (WFH). WFH is a work concept where employees can do their work from home. According to Crosbie and Mooroe, work from home is defined as a system of work where work is paid and done from home (at least 20 hours a week). ${ }^{32}$

The condition of WFH or working from home in the midst of a corona outbreak can be linked to the provisions of Article 86 paragraph (1) Letter of the Manpower Law which regulates "every worker/labor has the right to obtain protection for occupational safety and health". The concept of Work from Home (WFH) during the COVID-19 pandemic, apart from providing protection for workers, also has several advantages that can benefit companies and workers, as follows: ${ }^{33}$

a. Minimizing the company's operational costs, where the company can make efficiency on the cost of internet, electricity and other office operations.

b. Be more flexible in terms of working both in determining a comfortable place to work and time to do work.

c. Productivity has increased, as statistics from emailanalytic.com explain that WFH workers have increased their productivity by $77 \%$.

30 See Circular of the Minister of Manpower Number M/3/HK.04/III/2020 of 2020 concerning Protection of Workers/Labors and Sustainability Efforts in the Context of Prevention and Overcoming COVID-19.

31 Putra, C. V. A. (2017). Urgensi Klausula Definisi Dalam Perjanjian Kerja. Jurnal Ilmiah Fakultas Hukum Universitas Udayana, 63, 61.0. URL: https://ojs.unud.ac.id/index.php/kerthapatrika/article/view/32709/19795, accessed on $8^{\text {th }}$ of May 202

32 Ashal, R. A. (2020). Pengaruh Work From Home terhadap Kinerja Aparatur Sipil Negara di Kantor Imigrasi Kelas I Khusus TPI Medan. Jurnal Ilmiah Kebijakan Hukum, 14(2), 223-242.

${ }^{33}$ Dewayani, Tantri, (2020), Bekerja Dari Rumah (Work From Home) Dari Sudut Pandang Unit Kepatuhan Internal", Artikel DJKN, https:// www.djkn.kemenkeu.go.id/artikel/baca/13014/Bekerja-dari-Rumah-Work-FromHome-Dari-Sudut-Pandang-Unit-Kepatuhan-Internal.html, accessed on $2^{\text {nd }}$ of August 2020. 
d. Increase job satisfaction, where decreased stress levels can increase job satisfaction.

When employers impose WFH policies their workers, there are several options that can be made by employers to survive the company, namely as follows:

a. Employers continue to pay basic wages and allowances that are fixed in nature but do not pay non-permanent allowances.

b. The entrepreneur still pays the basic wage, but does not make allowance payments.

c. Employers deduct basic wages and do not pay allowances.

d. Employers do not pay workers' wages at all because workers are considered not doing work so they do not need to be paid wages.

These four things are possible in Minister of Manpower Circular Letter 03/2020 point II letter D. ${ }^{34}$

There are special rules regarding "sent home workers", which are regulated in a Circular of the Minister of Manpower, among others:

1. Minister of Manpower Circular Letter No: SE-05/M/BW/1998 concerning Wages for Workers who are Sent Home Not in the Direction of Termination of Employment, which regulates the following matters:

- Employers continue to pay wages in full, namely in the form of basic wages and fixed benefits as long as workers are dismissed, unless otherwise stipulated in the Work Agreement, Company Regulation or Collective Labor Agreement.

- If the employer will not pay the workers' wages in full, negotiate with the union and/or workers about the amount of wages during the time they are sent home.

2. Circular of the Minister of Manpower No: SE-907 / MEN / PHI-PPHI / X / 2004 concerning Prevention, which regulates the following matters:

If a company experiences difficult situation that can affect employment, termination of employment must be a last resort, after various efforts have been made, namely:

- Reducing wages and facilities for upper-level workers;

- Reducing Shift;

- Reducing Working Hours;

- Reducing the Working Day

- Leave or lay off workers/labors on a temporary basis. ${ }^{35}$

\footnotetext{
34 Sihombing, Irvin (2020), Pandemi, "Force Majeure", dan PHK, https://news.detik.com/kolom/d-5011359/pandemi-force-majeure-dan-phk accessed on 4th of August 2020.
} 
Therefore, if a worker/labor is sent home due to a public health emergency due to the COVID-19 virus pandemic, the worker/labor who is sent home still has the right to receive full wages or a reduction in wages if agreed by the company and the worker.

If a company is unable to pay its workers' wages in a public health emergency, due to the effect of restrictions on activities in the world of manpower and business has an impact on decreasing turnover or company profit income. Companies that are unable to pay workers 'wages are not allowed to immediately lay off their workers or not pay their workers' wages.

\section{Conclusion}

Company policy in the form of layoffs during the COVID 19 period can be justified as long as it complies with the provisions of Article 163 to Article 165 of the Manpower Law. The policy of temporarily laying off workers has not been regulated in the Manpower Law, but referring to Minister of Manpower Circular Letter 907/2004 and Minister of Manpower Circular Letter 5/1998, the act of laying off workers as a form of company saving is one effort that can be justified, provided that it shall complies with the provisions of the Minister of Manpower Circular Letter 5/1998. and Minister of Manpower Circular Letter 907/2004. The legal protection that should be obtained if workers are laid off in the midst of the COVID-19 pandemic is that workers have the right to receive severance pay of 1 (one) time (Article 156 paragraph (2) of the Manpower Law), work reward money of 1 (one) time (Article 156 paragraph (3) of the Manpower Law) and compensation money (Article 156 paragraph (4) of the Manpower Law). Legal protection that should be obtained if workers are sent home refers to the Minister of Manpower Circular Letter No: SE-05/M/BW/1998, that is, employers continue to pay wages in full as long as workers are sent home, unless otherwise stipulated in the Work Agreement, Company Regulation or Collective Labor Agreement and if the employer is not going to pay the workers 'wages in full, it shall first be negotiated with the workers' union and/or workers regarding the amount of wages during the workers sent home. The form of work relations/alternative policy models that can be offered to companies to ease the burden on the company and at the same time provide protection for workers amid COVID-19 is that companies can implement work relationships by doing Work From Home.

\section{Reference}

Book

Mertokusumo, Sudikno, (2000), Mengenal Hukum :Suatu Pengantar, Yogyakarta: Liberty. Darwin, Prints, (2000), Hukum Perburuhan Indonesia, Bandung:P.T. Citra Aditya Bakti.

Dimatteo, Larry A., and Dhooge, Lucien J., (2004), International Business Law, a Transactional Approach, Thomson West ed., 2nd ed.

Garner, Bryan and Campbell, Henry, (2019), Black's Law Dictionary, 11th ed., Thomson Reuters.

\footnotetext{
${ }^{35}$ See Circular of the Minister of Manpower and Transmigration of the Republic of Indonesia Number: 907/MEN/PHI-PPHI/X/2004 concerning Prevention of Mass Termination of Employment Relationships.
} 


\section{Journal}

Ashal, R. A. (2020). Pengaruh Work From Home terhadap Kinerja Aparatur Sipil Negara di Kantor Imigrasi Kelas I Khusus TPI Medan. Jurnal Ilmiah Kebijakan Hukum, $14(2)$,

223242.https://ejournal.balitbangham.go.id/index.php/kebijakan/article/view/11 $25 / \mathrm{pdf}$ (accessed on 28th of July 2020)

Berger, K. P., \& Behn, D. (2019). Force Majeure and Hardship in the Age of Corona: A Historical and Comparative Study. McGill J. Disp. Resol., 6, 76.DOI: http://dx.doi.org/10.2139/ssrn.3575869, accessed on 4th October 2020.

Casady, C. B., \& Baxter, D. (2020). Pandemics, public-private partnerships (PPPs), and force majeure| COVID-19 expectations and implications. Construction Management and Economics, 1-9.DOI: 10.1080/01446193.2020.1817516, (accessed on 4 th October 2020).

Eichenbaum, M. S., Rebelo, S., \& Trabandt, M. (2020). The macroeconomics of epidemics (No. w26882). National Bureau of Economic Research.https://www.nber.org/papers/w26882, (accessed on 4th October 2020)

Hadi, A. (2019). PERLINDUNGAN HUKUM TERHADAP KARYAWAN YANG MENGALAMI PEMUTUSAN HUBUNGAN KERJA SETELAH PUTUSAN PENGADILAN BERKEKUATAN HUKUM TETAP. Jurnal Surya Kencana Satu: Dinamika Masalah Hukum dan Keadilan, 9(2), 5370.https:// www.researchgate.net/publication/335272188_PERLINDUNGAN_H UKUM_TERHADAP_KARYAWAN_YANG_MENGALAMI_PEMUTUSAN_HU BUNGAN_KERJA_SETELAH_PUTUSAN_PENGADILAN_BERKEKUATAN_H UKUM_TETAP , (accessed on 18th of May 2020).

Juaningsih, I. N. (2020). Analisis Kebijakan PHK Bagi Para Pekerja Pada Masa Pandemi Covid-19 di Indonesia. 'ADALAH, 4(1).https:// www.google.com /search?q =journal thukum+ perlindungan

$\underline{\text { hukum+pekerja+terkena+dampak+PHK\&rlz=1C1CHBD_idID909ID909\&oq=jou }}$ rnal+hukum + perlindungan + hukum + pekerja+terkena + dampak + PHK\&aqs $=$ chro me..69i57.18542j0j7\&sourceid $=$ chrome\&ie=UTF-8\#, (accessed on $21^{\text {st }}$ of July 2020).

Katsivela, M. (2007). Contracts: Force Majeure Concept or Force Majeure Clauses. Unif. L. Rev. ns, 12, 101. DOI: 10.1093/ulr/12.1.101, (accessed on 4th October 2020)

Kusumawati, M. P. (2020). PERLINDUNGAN HUKUM PEKERJA PASCA PHK MELALUI PENGUNDURAN DIRI. Literasi Hukum, 4(1), 52-61. https://jurnal.untidar.ac.id/index.php/literasihukum/article/view/2385 (accessed on 30th of July 2020).

Mustakim, M., \& Syafrida, S. (2020). Pandemi Covid-19 Sebagai Alasan Force Majeure Dalam Melakukan Pemutusan Hubungan Kerja di Indonesia. SALAM: Jurnal Sosial dan Budaya Syar-i, 7(8), 695-706. http://journal.uinjkt.ac.id/index.php/salam/article /view/16552, (accessed on 3rd of August 2020)

Olivia, S., Gibson, J., \& Nasrudin, R. A. (2020). Indonesia in the Time of Covid-19. Bulletin of Indonesian Economic Studies, 56(2), 143-174.DOI: 10.1080/00074918.2020.1798581, (accessed on 4th October 2020)

Prajnaparamitha, K., \& Ghoni, M. R. (2020). Perlindungan Status Kerja Dan Pengupahan Tenaga Kerja Dalam Situasi Pandemi COVID-19 Berdasarkan Perspektif Pembaharuan Hukum. Administrative Law \& Governance Journal, 
3(2), 314-328.https://ejournal2.undip.ac.id/index.php/alj/article/view/8041, (accessed on $30^{\text {th }}$ of July 2020)

Putra, C. V. A. (2017). Urgensi Klausula Definisi Dalam Perjanjian Kerja. Jurnal Ilmiah Fakultas Hukum Universitas Udayana, 63, 61.URL: https://ojs.unud.ac.id/index.php/ kerthapatrika/article/view/32709/19795, (accessed on $8^{\text {th }}$ of May 2020).

HariPutri, A. R., \& Sonhaji, S. (2016). Perlindungan Hukum terhadap Hak-hak Pekerja yang Terkena Pemutusan Hubungan Kerja Akibat Efisiensi Perusahaan Berdasarkan Undang-undang Nomor 13 Tahun 2003 Tentang Ketenagakerjaan di Kota Semarang (Studi Putusan Ma Nomor 474/k/pdt. sus-phi/2013). Diponegoro Law Journal, 5(2), 1-21. https:/ / ejournal3.undip.ac.id/index.php/dlr/article/view/11102, (accessed on $28^{\text {th }}$ of April 2020).

Romlah, S. (2020). Covid-19 Dan Dampaknya Terhadap Buruh di Indonesia. 'ADALAH, 4(1).http://journal.uinjkt.ac.id/index.php/adalah/article Lview/16077, (accessed on 2nd of August 2020).

Sudiarawan, K. A., \& Dananjaya, N. S. (2018). KONSEP PENYELESAIAN PERSELISIHAN HUBUNGAN INDUSTRIAL BERBASIS PEMBERDAYAAN SEBAGAI UPAYA PENINGKATAN PERLINDUNGAN HUKUM TERHADAP BURUH DALAM MENCARI KEADILAN. ADHAPER: Jurnal Hukum Acara Perdata, 3(1), 17-37.http://jhaper.org/index.php/JHAPER/article/view/42, (accessed on $18^{\text {th }}$ of May 2020).

Utami, P. D. Y., Diantha, I. M. P., \& Sarjana, I. M. (2018). Kedudukan Hukum Grosse Akta Pengakuan Hutang Notariil dalam Pemberian Kredit Perbankan. Acta Comitas: Jurnal Hukum Kenotariatan, 3(1), 201-214., https://ojs.unud.ac.id/index.php/ActaComitas/issue/view /2742, (accessed on 3rd of August 2020)

\section{Internet}

Dewayani, Tantri, 2020, Bekerja Dari Rumah (Work From Home) Dari Sudut Pandang Unit Kepatuhan Internal", Artikel DJKN, https://www.djkn.kemenkeu.go.id/artikel/baca/13014/Bekerja-dari-Rumah-

Work-From-Home-Dari-Sudut-Pandang-Unit-Kepatuhan-Internal.html, accessed on $2^{\text {nd }}$ of August 2020.

Irvin Sihombing, 2020, Pandemi, "Force Majeure", dan PHK, https://news.detik.com/kolom/d-5011359/pandemi-force-majeure-dan-phk, accessed on $4^{\text {th }}$ of August 2020.

Joseph ginting, 2020, 2,8 Juta Buruhdi-PHK Dan Dirumahkan Di Tengah COVID-19, https://www.riauonline.co.id/citizen/read/2020/05/01/28-juta-buruhdi-phkdan-dirumahkan-di-tengah-COVID-19, accessed on 18th of May 2020.

Juanda Pangaribuan, 2018,Tata Cara Melakukan Pemutusan Hubungan Kerja Berdasarkan Undang-Undang No. 13 Tahun 2003", https://www. hukumonline.com/ berita / baca /1t5af2b67c1ec5d / formula-tepat-melakukan-phk-secara-hukum/, accessed on $28^{\text {th }}$ of April 2020.

Kena PHK di Tengah Corona, Bisakah Tuntut Perusahaan?" https:// finance. detik. Com /berita-ekonomi-bisnis/d-5010998/kena-phk-di-tengah-corona-bisakahtuntut-perusahaan, accessed on $16^{\text {th }}$ of May 2020.

International Labour Organization, "COVID-19 and the world of work: Impact and policy responses", 2020, Hlm.3, https://www.ilo.org/wcmsp5/groups/public/-- 
-dgreports/---dcomm/documents/briefingnote/wcms_738753.pdf, accessed on 4th October 2020.

\section{Laws and Regulations}

Law of the Republic of Indonesia Number 13 Year 2003 concerning Manpower, State Gazette Number 39, Supplementary State Gazette Number 4279.

Law of the Republic of Indonesia Number 2 Year 2004 concerning Industrial Relations Dispute Settlement, State Gazette Number 6, Supplementary State Gazette Number 4356.

Law of the Republic of Indonesia Number 11 Year 2020 concerning Job Creation, State Gazette Number 245, Supplementary State Gazette Number 6673.

Government Regulation of Republic of Indonesia Number 78 Year 2015 concerning Wages, State Gazette Number 237, Supplementary State Gazette Number 5747;

Decree of the Minister of Manpower and Transmigration Number KEP231/MEN/2003 Year 2003 concerning Procedures for Postponement of Implementation of Minimum Wages;

Minister of Manpower Circular Letter No. SE-05/M/BW/1998 of 1998 concerning Wages of Workers who are Sent Home Not in the Direction of Termination of Employment;

Circular of the Minister of Manpower and Transmigration of the Republic of Indonesia Number: 907/MEN/PHI-PPHI/X/2004 concerning Prevention of Mass Termination of Employment Relationships;

Circular of the Minister of Manpower Number M/3/HK.04/III/2020 concerning Protection of Workers/Labors and Business Continuity in the Context of Prevention and Disaster Management of COVID -19.

UNIDROIT Principles of International Commercial Contracts, pp.240-242, https://www.unidroit.org/english/principles/contracts/principles2016/princi ples2016-e.pdf, accessed on 4th October 2020.

International Chamber of Commerce Force Majeure Clause, 2020, point.3(e), p.2, https://iccwbo.org/content/uploads/sites/3/2020/03/icc-forcemajeurehardship-clauses-march2020.pdf, accessed on 4th October 2020. 